\title{
PALEOBIOGEOGRAPHIC AND PALEOGEOGRAPHIC SIGNIFICANCE OF PERMIAN BRACHIOPOD FAUNAS OF THE BILK CREEK LIMESTONE, NEVADA, AND THE McCLOUD LIMESTONE, CALIFORNIA.
}

HANGER, Rex Alan, Museum of Paleontology and Department of Integrative Biology, University of California, Berkeley, CA 94720 U.S.A.

The Bilk Creek Limestone of the Black Rock Terrane in northwestern Nevada and the McCloud Limestone of the Eastern Klamath Terrane in northern California contain a diverse and abundant Permian brachiopod fauna currently under study. The composite rock record of both limestones spans the Wolfcampian and Leonardian stages of the Permian, during which both terranes were part of a volcanic arc separated from the North American continent by a marginal basin of unknown dimension. Brachiopods of this volcanic arc provide important evidence bearing on current hypotheses of Permian paleobiogeography and paleogeography.

The Bilk Creek/McCloud brachiopods are best characterized as an endemic fauna of a unique province and not as a mixed, "Tethyan" and North American fauna. The central problem of these arc faunas is not how similar they are to faunas of the Tethyan basin but why they are so dissimilar from North American faunas. Overlying rock units in both terranes contain Guadalupian brachiopod faunas that are North American in character. The paleobiogeographic pattern is one of decreasing levels of endemism throughout the Wolfcampian and Leonardian, to ultimate deprovincialization during the Guadalupian. This is not consistent with a pantropic dispersal hypothesis.

The temporal pattern is consistent with a paleogeographic hypothesis of initial, long-distance separation of arc and continent with convergence of the arc toward the North American continental margin. The dissimilarity of the arc brachiopod faunas to coeval, same-environment faunas of North America suggests that the marginal basin that separated the two must have been several thousand kilometers wide during the Early Permian, producing the endemic fauna. A Japan-style model, with arc and continent in close proximity is not supported. 